\title{
Contabilidade rural: Estudo de caso da cultura do feijão e da soja na região de Jussara-Goiás no período 2014/2015.
} \author{
$\underline{\text { Barros Cintra }}^{2}$; $\underline{\text { Clesiomar Rezende Silva }}^{2}$ \\ ${ }^{1}$ Discentes do curso de Ciências Contábeis, Faculdade de Jussara - FAJ. \\ ${ }^{2}$ Contador, Professor especialista, Faculdade de Jussara - FAJ. \\ ${ }^{3}$ Zootecnista, Professora mestre, Faculdade de Jussara - FAJ. \\ *Autor para correspondência, E-mail:gracielecaetano@outlook.com
}

Daniela Ferreira de Souza ${ }^{1}$; Julio Cesar Silvestre Ferreira ${ }^{1}$; Karla Conceição de Oliveira ${ }^{\mathbf{1}}$; Djalma Aparecido Alves de Brito ${ }^{2}$; Graciele Araújo de Oliveira Caetano ${ }^{3}$; Denise Gomes

\begin{abstract}
RESUMO. A contabilidade existe desde as antigas civilizações, quando o homem nem mesmo conhecia o sistema de registro convencional. Porém, diante da necessidade de acompanhar a evolução de seu rebanho, criou o sistema de registro através de riscos em árvores ou pedras, e a partir desse momento a contabilidade passou a fazer registro da vida do homem e ela evoluiu durante todo o processo histórico da humanidade. Somente no início do século XIX, a contabilidade deixou de ser um mero instrumento de prestação de informação. Quando partimos para o meio rural temos hoje, de forma mais precisa e controlada, a contabilidade não somente para averiguar as cabeças de animais existentes na propriedade, mas uma forma de controlar o patrimônio rural familiar de forma geral, orientando entradas e saídas da propriedade administrando assim todo fluxo de caixa, pois a propriedade rural é também uma empresa, sendo o empresário seu próprio proprietário sendo as atividades desenvolvidas na propriedade rural. Dentro desse cultivo tem-se a pecuária e a agricultura, e na parte agrícola temos a produção vegetal, com sua cultura temporária ou permanente. Para que a propriedade tenha sucesso, faz-se necessário atentar-se aos custos de despesas que o investimento requer, sendo relevante tanto os custos variáveis como os fixos. A cultura do feijão é um exemplo de cultivo temporário, que requer um clima moderado com chuvas não muito intensas; já a soja é a campeã de desenvolvimento nas últimas três décadas. A pesquisa de campo nos mostrou a real situação do cultivo do feijão e da soja dentro do campo contábil, avaliando desde os gastos com a preparação do solo à venda do produto tendo assim os reais valores de entradas, saídas e o lucro e qual dos dois produtos tem maior rentabilidade.
\end{abstract}

Palavras-Chave: Evolução da contabilidade, contabilidade rural, patrimônio rural.

\section{Rural accountancy: Case study of the bean crop and soybeans in Jussara, Goiás in the period 2014/2015.}

\begin{abstract}
Accountancy existed since the ancient civilizations, when the man did not even know the conventional counting system, but with the need to follow the evolution of his flock, the counting system with scratches on trees or stones, as from that moment the accounting has become part of man's life and it has evolved throughout the historical process of humanity. Only in the early nineteenth century that accounting ceased to be a simple tool for providing information. In the rural area, we have today a more precisely and controlled accounting, not only to ascertain the heads of animals in the property, but a way to control the familiar rural heritage in general, directing property's inputs and outputs, managing all cash flows, because the farm is also a company, being the entrepreneur its own proprietary. Inside the culture ranching and farming, we have the crop production portion with the temporary or permanent culture. For the property success it is necessary to pay attention to the costs of expenses, that investment requires being both relevant, variable and fixed costs. The bean crop is a temporary cultivation
\end{abstract}


and requires a moderate climate with not very heavy rainfall, and the soy is the development champion for the last three decades. This field research showed us the real situation of bean cultivation and soy, inside the accounting field, evaluating since spending on soil preparation for sale of the product thus having the actual values of inputs, outputs and profits and which products have higher profitability.

Keywords: Accountancy evolution, rural accountancy, Rural Heritage.

\section{Introdução}

A contabilidade rural é o ramo da atividade que estuda o patrimônio rural, composto por ativos como: caixa, cabeças de gado, terra, tratores, estoques de produtos agrícolas (fertilizantes e sementes), também compostas por passivos como: empréstimos bancários, obrigações dos trabalhadores, fornecedores, e saldo líquido (capital, reservas, etc.). As empresas rurais apresentam características muito especificas em virtude da sucessão de acontecimentos como a periodicidade e a especialidade de cada ramo de atividade rural.

Segundo Marion (2003, p.22) empresas rurais são aquelas que exploram a capacidade produtiva do solo por meio do plantio da terra, da criação de animais e da mutação de alguns específicos produtos agrícolas.

É considerado como atividade rural o cultivo das atividades agrícolas, pecuárias, a extração e a exploração vegetal e animal, a exploração da apicultura, avicultura, suinocultura, sericicultura, piscicultura e outras atividades voltadas à produção de animais de pequenos portes, a transformação de produtos agrícolas ou pecuários (sem que sejam alteradas a composição e as propriedades do produto in natura), realizada pelo próprio agricultor ou criador, que são aqueles que cultivam a capacidade fértil do solo, por meio do cultivo agrário ou pecuária na criação de animais e da modificação de determinados produtos agrícolas.

Crepaldi (2004, p. 62) relata que a contabilidade rural é uma ferramenta pouco utilizada pelos empresários rurais, pois é vista como uma técnica complexa, com baixo retorno na prática e é conhecida apenas para a Declaração de Imposto de Renda, onde os produtores não demonstram interesse na sua aplicação gerencial. Dentre outros fatores, o autor ressaltou que o que tem contribuído para isso é a carência dos sistemas contábeis, responsáveis em desdizerem-se as características da atividade agropecuária, bem como a falta de profissionais licenciados na difusão de tecnologias administrativas aos produtores rurais, logo esse é o porquê de não incluir a contabilidade rural como instrumento de políticas governamentais agrícolas ou fiscais.

A pesquisa realizada apresentou a real situação de como funciona a agricultura do cultivo da soja e do feijão, bem como todas as despesas, entradas e saídas desde a preparação do terreno à venda do produto. Como o cultivo da soja tem crescido muito nas últimas três décadas e sua forma de plantio tem sido cada vez mais na forma de pivô central, o que não é diferente com o feijão que também é produzido o ano todo na região de Jussara. Faz-se necessário utilizar bons produtos para que o retorno seja garantido, desde $\mathrm{o}$ maquinário às sementes, fertilizantes e fungicidas. Acompanhar cada progresso de perto é a garantia de não se ter surpresas desgastantes no final da safra. Percebe-se que mesmo a soja tendo uma área maior em cultivo, o feijão ainda é mais favorável na referida região, pois o valor da saca do grão que não pode faltar na mesa do brasileiro, é maior de idade valor e possui menor variação de preço por safra.

\section{Evolução da contabilidade}

A contabilidade existe deste o início das civilizações, quando o homem despertou a necessidade do conhecimento da proporção que seu rebanho aumentava de um período para outro. Neste período já existiam os desafios de querer ver sua riqueza aumentando.

Segundo Iudícibus \& Marion (2002, p.29), imagine um homem, na antiguidade, sem conhecer números e, muito menos, a escrita, exercendo a atividade de pastoreio. O inverno esta chegando. $\mathrm{O}$ homem prepara toda a provisão para o sustento do seu rebanho de ovelhas olhando para um período longo de muito frio que esta se aproximando. Ainda que ele nunca tenha aprendido sobre os meses do ano, ele sabe se a neve esta se aproximando, pois as folhas das árvores ficaram amarelas e caíram e assim ocorreu no passado por inúmeras vezes. Ele não sabia o que eram estações do ano, mas tinha 
experiência: arvore secando, frio chegando. À medida que o homem possuía maiores quantidades de rebanho, maior era sua preocupação em saber qual seria sua renda e qual seria a forma mais simples de aumentar as suas posses; além disso, à medida que o patrimônio crescia, ficava cada vez mais difícil a memorização, necessitando então dos registros. Foi ponderando o futuro promissor que levou o homem a realizar seus primeiros registros para que pudesse avaliar as suas autênticas possibilidades de uso, de consumo, de produção etc. Sendo assim o homem começa a fazer marcas em árvores e pedras, podendo assim conferir seu rebanho em termos de crescimento, de perdas de ovelhas, mortes, entre outros acontecimentos.

A contabilidade veio se desenvolvendo de acordo com as necessidades de cada período histórico. Desde o aparecimento da escrita até a revolução industrial, foi grande o marcos da nossa história que contribuíram para o desenvolvimento da ciência contábil.

Segundo Iudícibus e Marion (2006, p.34), na idade moderna, por volta dos séculos XIV a XVI, principalmente no renascimento, diversos acontecimentos no mundo das artes, na economia, nas nações proporcionaram um impulso espetacular das Ciências Contábeis, sobretudo na Itália. Com o passar dos tempos, a necessidade de aperfeiçoar e de registrar todos os fatos econômicos, fez com que a contabilidade fizesse cada vez mais parte das políticas e transações comerciais.

O desenvolvimento da contabilidade em toda a sua historia esteve intimamente ligado ao desenvolvimento econômico, as transações sociopolíticas e socioculturais experimentadas em cada época. O homem foi sentindo a necessidade de aperfeiçoar seu instrumento de avaliação da situação patrimonial, ao mesmo tempo em que as atividades econômicas foram se tornando mais complexas (Nagatsuka \& Teles, 2002). Segundo referido os autores, a evolução histórica da contabilidade se resume em duas grandes escolas, a Italiana e a Norte Americana.

Iudicibus $(2006$, p.41) foi com a fundação da Faculdade de Ciências Econômicas e administrativas da USP, em 1946, e com a instalação do curso de Ciências Contábeis e Atuariais, que o Brasil ganhou o primeiro núcleo efetivo, embora modesto, de pesquisa contábil nos moldes norte americanos. Ainda, de acordo com o autor, a escola norte-americana além de aprimorar as técnicas de registros advindas da escola Italiana, também aprimorou as técnicas de auditoria desenvolvidas pelos Ingleses.

$\mathrm{Na}$ década de 1960 surgem os primeiros traços da influência americana na metodologia do ensino da contabilidade. Isso propiciou a mudança da Escola Italiana para a Escola Americana, com a entrada das empresas de auditoria anglo americanas que acompanhavam as multinacionais que há pouco tempo haviam chegado ao Brasil. Os autores Iudícibus e Marion (2006, p.36) relatam que no início do século XX houve a queda da chamada Escola Européia (mais especificamente a Italiana) e a ascensão da chamada escola norte americana no mundo contábil. Segundo Niyama (2013, p.64), a evolução da história e da teoria contábil norteamericana tem sua origem no início do século XIX, com a segunda Revolução Industrial, em que a contabilidade deixou de representar um instrumento de controle da riqueza patrimonial do proprietário para se constituir importante instrumento de prestação de informações para a decisão de diversos usuários.

\section{Contabilidade Rural}

Contabilidade rural é a parte da contabilidade que analisa o patrimônio rural, onde se trata de um dos fundamentais sistemas de influência de informação das empresas rurais, o qual gera informações para tomada de decisão, demonstrando toda uma evolução da vida da empresa. É de grande importância para o produtor rural, pois é uma ferramenta que permite o planejamento e controle dos custos e a comparação dos resultados por meio de informações contábeis.

Segundo Crepaldi (2004, p.62), a contabilidade rural é uma necessidade urgente no Brasil, porém ainda não muito utilizada, tanto pelos empresários quanto pelos contadores.

A contabilidade rural surgiu da necessidade de controlar o patrimônio. É fato que existem pessoas, entidades e empresas que realizam muitas transações, decorrendo daí maior complexidade de controle. Seria impossível controlar um patrimônio, que é um conjunto de bens, direitos e obrigações, sem que houvesse registros organizados de todas as mutações ocorridas (Crepaldi, 2012 p.85-86). A contabilidade rural tem como finalidade orientar as operações das empresas tanto no ramo agrícola 
quanto pecuária, mensurar e verificar o desempenho econômico financeiro da empresa, levando a uma administração eficiente. A mesma surgiu para ser parceira do produtor rural, trazendo maior controle das operações desde a movimentação de fluxo do caixa até a tomada de decisão coerente e eficaz para seu negócio.

De acordo com Crepaldi (2005, pg. 83-84) a contabilidade rural tem como finalidades: Orientar as operações agrícolas e pecuárias; Medir o desempenho econômico-financeiro da empresa e de cada atividade produtiva individualmente; Controlar as transações financeiras; Apoiar as tomadas de decisões no planejamento da produção, das vendas e dos investimentos; Auxiliar as projeções de fluxo de caixa e necessidades de crédito; Permitir a comparação da performance da empresa no tempo, e desta com as outras empresas; Conduzir as despesas pessoais do proprietário e de sua família; Justificar a liquidez e capacidade de pagamento da empresa junto aos agentes financeiros e outros credores; Usar informações para a declaração do IR.

Crepaldi (1998, p.75-76), aponta a contabilidade como um dos principais sistemas de controles em formação para as empresas rurais, podendo, através de seus instrumentos averiguarem a situação da empresa sob os mais diversos enfoques, tais como, análise estrutura, de evolução, solvência, de segurança de garantia de capitais próprios e de terceiros, de retorno de investimento, entre outros.

Segundo Marion (2002, p.25), a contabilidade rural quando estudada de forma genérica é denominada contabilidade geral ou contabilidade financeira. Quando aplicada a um ramo específico, normalmente e denominada de acordo com a atividade daquele ramo. Assim, há: contabilidade agrícola é a contabilidade geral aplicada às empresas agrícolas; contabilidade rural: é a contabilidade geral aplicada às empresas rurais; contabilidade da zootecnia: é a contabilidade geral aplicada às empresas que exploram a zootecnia. contabilidade da pecuária: é a contabilidade geral aplicada às empresas pecuárias; contabilidade agropecuária: é a contabilidade geral aplicada às empresas agropecuárias; contabilidade da agroindústria: é a contabilidade geral aplicada às empresas agroindustriais (Marion, 2002, p.26). Segundo Crepaldi $(2012$, p.205) a contabilidade rural é a contabilidade geral aplicada nas atividades agrícolas, pois utiliza a capacidade do solo através dos meios apropriados que permitem obter os produtos da natureza com maior abundância e mais economia.

O principal objetivo da contabilidade rural é estudar, controlar e registrar a gestão econômica do patrimônio rural que se dedicam a esses fins, portanto, reserva-lhe particularidades específicas que lhe são inerentes.

\section{Empresário Rural x Contador}

Devido ao crescimento do mercado agropecuário, o contador rural tem conquistado um papel cada vez mais relevante, tornando de suma importância para o produtor rural, com suas práticas de controle e planejamento, garantindo assim a continuidade do trabalho.

Para Crepaldi (1998) o contador será cada vez mais importante neste segmento da economia, à medida que este for crescendo e se tornando mais complexo para se administrar. A contabilidade rural é uma ferramenta de gestão que deve ser implantada, mas, no entanto não é uma tarefa muito fácil devido grandes dificuldades na coleta de informações, conhecimento da legislação e outras. O contador tem buscado esta aproximação com produtor rural e entidades ligadas ao setor, tentando demonstrar o quanto é de suma importância à presença do contador para estar ajudando e avaliando a necessidade de cada setor indicando assim as melhores opções de negócios para aproveitar oportunidades e aumentar assim cada vez mais a rentabilidade. Segundo Marion (2005, p.25) a contabilidade é a linguagem dos negócios.

Crepaldi (2005, p.68) assegura que: A contabilidade sempre foi reconhecida pela sua capacidade de gerar informações técnicas, como também pelos seus aspectos motivacionais nela implícita, uma vez que ela nunca perdeu de vista sua responsabilidade como meio de comunicação estreitando a sua relação entre seus usuários.

O produtor rural deve se conscientizar de que a contabilidade é uma ferramenta importante de gestão, onde o planejamento e o controle da produção são indispensáveis em qualquer tipo de empresas, independente de seu tamanho, sendo considerada uma tarefa intensa e complexa para o contador. Pois só diante da conscientização que o contador estará desempenhando a sua função de gerar informações benéficas para a tomada de decisão e em sequência o crescimento da empresa. 


\section{A Empresa Rural}

Empresa rural é a unidade de produção na qual são exercidas atividades que dizem respeito às culturas agrícolas, pecuárias, a extração e a exploração vegetal e animal com finalidade de obtenção de lucros. Segundo Crepaldi (2012, p.3): Empresa rural é o empreendimento de pessoa física ou jurídica, publica ou privada, que explore econômica e racionalmente imóvel rural, dentro de condição de rendimento econômico da região em que se situe e que explore área mínima agricultável do imóvel segundo padrões fixados, publica e previamente, pelo Poder Executivo.

Uma empresa para se enquadrar no direito, deve ter uma visão entre as partes sendo, o empresário, a atividade econômica organizada e o estabelecimento. Adquirindo esse conhecimento, o empresário é o próprio produtor rural, sendo pessoa física ou jurídica e a atividade econômica organizada é o intercâmbio de bem e serviços e o estabelecimento é o local onde se desenvolve essa atividade, que é a propriedade rural. Segundo Marion (2005), empresa rural é aquela que explora a capacidade produtiva do solo por meio do cultivo da terra, da criação de animais e da transformação de determinados produtos agrícolas. O campo de atividades da empresa rural pode ser dividido em três grupos distintos: produção vegetal, produção animal e indústrias rurais.

Dentro de uma empresa rural a função financeira e contábil é bem parecida, porém a função contábil é mais bem concebida como um insumo indispensável à função financeira, isto é, como sub-função da administração financeira. De modo geral, devemos levar em conta que a função contábil deve ser sempre controlada pelo empresário rural, porém, há dois atenuantes básicos de probabilidades entre a administração financeira e a contabilidade: a diferença entre as duas é que uma refere-se ao tratamento de fundos e a outra, à tomada de decisão.

Segundo Crepaldi (2012, p.45) o empresário rural deve cuidar em desempenhar a função de administrar financeiramente seu empreendimento, já que a maioria das decisões precisa ser de algum modo medido em termos financeiros. Dentro de uma empresa a função financeira vai depender de seu porte, o conhecimento financeiro vai auxilia no planejamento, na resolução dos problemas e tomadas de decisões.

\section{Arrendamento}

Arrendamento é um modelo de contrato agrário, onde o proprietário de um terreno ou bem, que é denominado arrendador cede determinado terreno ou bem, para o arrendatário por tempo determinado ou não, para que este possa exercer a exploração do terreno em atividades agrícolas, pecuárias, agroindustrial, mediante pagamento pré-fixados sobre o uso, sendo esse em dinheiro ou em bens, observando os percentuais legais, tal pagamento será realizado independentemente do resultado do empreendimento.

Segundo o autor Marion (2002, p.32) arrendamento é quando o proprietário da terra aluga seu capital fundiário por determinado período à um empresário. $\mathrm{O}$ arrendador recebe do arrendatário uma retribuição certa, que é o aluguel.

No contrato de arrendamento deve constar: o lugar e data da assinatura do contrato, nome completo e endereço dos contratantes, características do arrendador e arrendatário ou do parceiro-outorgante e parceiro-outorgado; Objeto do contrato; Tipo de atividade de exploração; Destinação do imóvel ou dos bens, identificação do imóvel e número do Registro no Cadastro de Imóveis Rurais - IBRA, descrição da gleba, enumeração das benfeitorias e demais bens e facilidades, prazo de duração e preço, foro do contrato, cláusulas obrigatórias do Regulamento; Assinatura dos contratantes ou da pessoa a seu rogo e de quatro testemunhas idôneas (Anexo 1).

Quanto às obrigações, o arrendatário tem por utilizar o imóvel ou bem arrendado como se fosse seu, devendo preservá-lo e ao fim do contrato tem por obrigação devolvê-lo ao arrendador nas condições em que recebeu, caso isso não ocorra, implicará em infração legal, onde o arrendador poderá rescindir o contrato e despejá-lo, além de ressarcimento por perdas e danos. Quanto ao arrendador cabe a entrega do bem ou terreno arrendado em condições de uso conforme o contrato estabeleceu.

\section{Atividades Agrícolas}

$\mathrm{Na}$ atividade agrícola produção vegetal se detém basicamente no cultivo e práticas produtivas. Segundo Marion (2002, p.24) a atividade agrícola pode ser dividida em dois grandes grupos: Culturas hortícola e forrageira: cereais (feijão, soja, arroz, milho, trigo, aveia...); hortaliças (verduras, tomate, pimentão...); 
tubérculos (batata, mandioca, cenoura...); plantas oleaginosas (mamona, amendoim, menta...); especiarias (cravo, canela...); fibras (algodão, pinho...); floricultura, forragens, plantas industriais; e Arboricultura: florestamento (eucalipto, pinho...); pomares (manga, laranja, maça...); vinhedos, olivais, seringais.

A atividade agrícola é classificada contabilmente em duas culturas, sendo a cultura temporária e a permanente. Culturas temporárias essencialmente são aquelas que apresentam um período de vida mais curto, podendo ser replantadas após a colheita, quando são extraídas do solo para a efetivação de um novo plantio e não sobrevive mais que um ano.

Culturas temporárias são aquelas sujeitas ao replantio após cada colheita, como milho, trigo, feijão, arroz, cebola etc. Nesse caso, os dispêndios para a formação da cultura serão considerados, no período de sua realização, despesas de custeio (Marion, 2002, p.98).

Culturas constantes são aquelas com um período de vida superior a um ano, que não são culturas anuais e não estão sujeitas a replantio após a colheita. Pois estão vinculadas ao solo, proporcionando mais de uma colheita, sendo fator de produção da entidade por vários anos.

Segundo Marion (2002, p.41) culturas permanentes são aquelas que normalmente não são replantadas após cada colheita: São aquelas que permanecem vinculadas ao solo e proporcionam mais de uma colheita ou produção. Normalmente atribui-se as culturas permanentes uma duração mínima de quatro anos. Do nosso ponto de vista basta apenas uma cultura durar mais de um ano e propiciar mais de uma colheita para ser permanente. Exemplos: cana-de-açúcar, citricultura (laranjeira, limoeiro...), cafeicultura, silvicultura (essências florestais, plantações arbóreas), oleicultura (oliveira), praticamente todas as frutas arbóreas (maça, pêra, jaca, jabuticaba, goiaba, uva...).

\section{Custos e despesas}

Os custos são valores com gastos de bens e serviços no cultivo de outros bens e serviços. Identificados direta ou indiretamente com a cultura, ou seja, esses são relativos à atividade de produção, são gastos incorridos necessários para aquisição até o momento de colocar o produto em elaboração a ponto de serem vendidos.
Os custos, segundo Crepaldi (2012, p.100) são gastos (ou sacrifícios econômicos), relacionados com a transformação de ativos (exemplo: consumo de insumos ou pagamento de salários).

Os custos são subdivididos em duas categorias, sendo custos variáveis e custos fixos. Os custos variáveis alteram em relação ao nível de produção ou atividades, seus valores mudam em relação ao volume produzido e os volumes de vendas são assim chamados pelo fato de que seus valores dependem da intensidade da utilização do maquinário. Exemplos: combustível, lubrificantes, manutenção e consertos.

Custo variável total, ou CVT, é o curso de recursos com duração igual ou menor que o ciclo de produção. Em outras palavras, são recursos aplicados e/ou consumidos em curto prazo, incorporando-se totalmente ao produto. Resultam da soma dos gastos com insumos (sementes, defensivos, fertilizantes e medicamentos), serviços em geral prestados por mão de obra braçal, técnica e administrativa, serviços de maquinas e equipamentos, conservação dos bens empresariais e juros. (Crepaldi, 2012, p.162).

Custos fixos são aqueles que não sofrem alteração no seu valor em relação ao aumento ou diminuição da produção. As possíveis variações na produção não alteram seus valores fixados, são assim chamados porque ocorrem independentemente do uso ou não do maquinário. Custo fixo total, também conhecido pela sigla, CFT, é o custo de recursos com duração superior ao ciclo de produção, ou seja, não se incorpora totalmente ao produto no curto prazo, fazendo-se em tantos ciclos quanto permitir sua vida útil. É o resultado da soma dos custos de terra, benfeitorias, maquinas e equipamentos, lavouras permanentes, animais produtivos e de trabalho, impostos e taxas fixas. (Crepaldi, 2012, p.163).

As despesas nada mais são que gastos não identificáveis com a cultura/produção, referente à manutenção da atividade da empresa Segundo Marion (2002, p.38). Como despesa do período, entende-se todos os gastos não identificáveis com a cultura, não sendo, portanto, acumulados no estoque (culturas temporárias), mas apropriados como despesa do período. São as despesas de venda (propaganda, comissão de vendedores...) e despesas administrativas (honorários dos diretores, pessoal de escritório...) e despesas financeiras (juros, correção monetária). 
É importante destacar que na contabilidade despesa não é o mesmo que custo, uma vez que custo está relacionado ao processo de produção de bens ou serviços; já despesa engloba em geral os gastos das atividades em produção e de manutenção com as empresas.

\section{O agronegócio e a produção de alimentos no Brasil}

O termo agricultura foi comum até bem recentemente para entender a produção agropecuária em toda sua extensão, desde o abastecimento de insumos necessários, da produção até a industrialização. Desde então nas últimas décadas, esse setor econômico passou por muitas modificações, tornando mais difíceis e abrangentes. Segundo Araújo (2007, p.09). As transformações foram tão grandes que o entendimento do setor somente como agricultura passou a ser insuficiente, porque as atividades, antes desenvolvidas quase exclusivamente dentro das fazendas, passaram a ser efetuadas predominantemente fora, tanto antes como depois da produção agropecuária propriamente dita.

Para que ocorra a produção agropecuária e para que o produto chegue até o consumidor antes passa por varias atividades social como agronômicas, zootécnicas, logísticas e outras. Com isso a produção agropecuária deixou de ser caso de agrônomos, veterinários, agricultores e de pecuaristas para ocupar um contexto muito complexo e abrangente, que é do agronegócio.

De acordo com o autor o agronegócio é o segmento econômico de maior valor em termos mundiais, e sua importância relativa varia para cada país.

No Brasil, o agronegócio foi estimado, para o ano de 2004, em aproximadamente $\mathrm{R} \$ 524,8$ bilhões, significando mais de $31 \%$ do PIB. O negocio brasileiro tem grande importância na balança comercial, participando com mais de $40 \%$ da pauta de exportação e sendo altamente superavitário, de modo a contribuir sensivelmente para evitar os déficits comerciais do Brasil (Araújo, 2007, p.28).

Nas últimas safras o agronegócio brasileiro sofreu forte crise, principalmente o negócio de grãos, exceto com a cana, café, suco de laranja, papel e celulose. Essa situação foi agravada pela quebra de safra em função da estiagem, que obteve como resultado uma situação de endividamento do setor rural.
Essa situação de endividamento dos produtores rurais faz com que haja redução no uso de tecnologia na lavoura, maior sensibilidade ao ataque de pragas e doenças e baixa qualidade do produto final.

Mesmo diante dessa crise, Neves (2007, p.17) ressalta que não podemos deixar de lembrar que o agronegócio brasileiro é um modelo de sucesso, uma referência para as demais nações do globo, pela sua competitividade alcançada principalmente na década de 90, pósdesregulamentação de muitas de suas cadeias produtivas.

O que distingue o Brasil dos demais países produtores de alimentos é a Bioenergia, pois o Brasil tem capacidade de produzir mais, pois tem o domínio da tecnologia que permite produzir em regiões tropicais, onde há muita luz e calor, o que favorece a produção de dois a três cultivos na mesma terra e no mesmo ano.

O Brasil vem se destacando em primeiro lugar na produção mundial de feijão, café, açúcar e suco de laranja, ficando em segundo lugar na produção de soja, de carne bovina, de tabaco e de álcool.

\section{A agricultura}

\section{Cultura do Feijão}

O Feijão é uma planta leguminosa cultivada desde os tempos mais remotos da nossa história, sempre com o alvo de ser consumido na forma de alimento. É um vegetal que exige pouco, necessitando apenas de solos de fertilidade média e climas que não sejam nem muito quente ou frio, muito chuvoso ou muito seco. Portanto, pode-se realizar o plantio de feijão com uma possível agilidade em quase todas as áreas agrícolas do nosso planeta. Um dos produtos da agricultura da mais alta extensão econômica e social, um dos alimentos considerado como básico na mesa da cultura brasileira, é a principal fonte de suprimento proteico das classes de menor renda da população brasileira.

O Brasil é o maior produtor de feijão comum, um vegetal da família da leguminosa (Phaseolus vulgaris) em que suas vagens e sementes são riquíssimas em valor nutritivo. Segundo Silva (2004) apud Silveira et al 2014, o Brasil é o segundo maior produtor mundial de feijão do gênero Phaseolus e o primeiro na espécie Phaseoolus vulgaris. A importância da produção de feijão, além de constituir um dos alimentos 
básicos da produção brasileira, ao lado do arroz, sendo também um dos principais produtos fornecedores de proteína.

O feijão é um alimento muito rico em diferentes nutrientes para o organismo humano, proporcionando uma composição média com os seguintes valores: $64 \%$ de carboidratos, $25 \%$ de proteínas e $11 \%$ de gorduras. Contêm ainda uma grande concentração de vitaminas $\mathrm{B}$ e C, ácido cítrico: sacarose, globulina, entre outros componentes.

Segundo Silva (2004) apud Silveira et al 2014, o consumo atual do feijão no Brasil é cerca de $16 \mathrm{~kg} /$ habitante/ano, existindo preferência de coloração, tipo do grão e a propriedade culinária em algumas regiões do país.

O feijão é produzido em mais de 100 países, porém o Brasil e a Índia, que juntos respondem por mais de $33 \%$ colheita global, dominam a produção mundial. O Brasil é o país de maior produção e consumo mundial, com 3,3 milhões de toneladas produzidas.

De acordo com Ferreira; del Peloso; Faria (2002) apud Reis (2006) a oferta de feijão no Brasil vem passando por profundas mudanças. Atualmente, a primeira colheita (safras das águas), consiste principalmente nas regiões Sul e Sudeste e na região de Irecê. $O$ plantio do feijoeiro normalmente é realizado em duas épocas do ano a das águas, e a da seca. Tanto o excesso de chuvas como a falta dela, como o excesso de calor ou as temperaturas muito baixas poderão prejudicar sensivelmente a cultura do feijão. No entanto, regiões que apresentem condições favoráveis de temperatura são passiveis de irrigação, sendo assim uma terceira época de plantio poderá acontecer, que é o plantio de inverno. Uma vantagem bastante ponderável do plantio fora de época é que o feijão da safra atual entrará no mercado fora de época e, logo será mais valorizado.

\section{Cultura da Soja}

A soja é a tradição agrícola brasileira que mais obteve crescimento nas últimas três décadas e corresponde a aproximadamente $49 \%$ da área cultivada em grãos no país, é uma qualidade de planta rasteira leguminosa, que hoje é cultivada mundo a fora. O grão é o ingrediente substancial na fabricação de rações animais e com o uso crescente na alimentação humana, se encontrando em espontâneo crescimento.
O grão de soja se evoluiu com o aparecimento de plantas oriundas de cruzamentos naturais de duas espécies de soja selvagem, que foram domesticadas e aperfeiçoadas por cientistas da China. Chegou ao Brasil via Estados Unidos no ano de 1882, mas foi somente a partir dos anos 40 que ela ganhou importância econômica. A soja é uma planta herbácea pertencente à família das leguminosas, subfamília das Papilionáceas e à tribo das Faseoláceas, geralmente anual, raramente perene. É ereta ou volúvel, protumbente. $\mathrm{O}$ caule e ramoso, híspido, com 80 a $150 \mathrm{~cm}$ de comprimento. As folhas são longo pecioladas, com 3 folíolos cordiformes, muito desenvolvidos e peludos na parte inferior. (Gomes, 1997, p.12)

A soja se estabeleceu como cultura economicamente importante para o Brasil a partir da década de 1960, quando foi impulsionada pela política de subsídios ao trigo, visando autossuficiência. Mesmo com todo esse crescimento econômico de grande importância no decorrer dos anos 60, foi apenas na década de 70 que a soja estabilizou como a principal cultura do agronegócio brasileiro. Cultivada, sobretudo nas regiões Centro Oeste e Sul do país, se firmou como um dos produtos mais notáveis da agricultura e na balança comercial.

Segundo Gomes (1997, p.11) em 1995 o Brasil produziu 106.000 toneladas de soja, em números redondos; em 1960, 205.000; em 1965, 523.000. Em 1970, 1.508.000. em 1971, 2.100.000 toneladas. O Centro-Oeste é o segundo maior produtor de soja no país, ocasionando assim um crescimento elevado no Brasil. Muitos fatores auxiliaram para que a soja introduzisse como uma importante cultura nacional, primeiramente no Sul e em seguida nos Cerrados do Brasil, dentre esses fatores alguns que se destacam são: a conformidade do ecossistema do sul do Brasil com a do sul dos EUA; a troca das gorduras animais por óleos vegetais; estabelecimento da Operação Tatu no RS facilitando o cultivo da soja naquele estado; mercado internacional em alta; incentivos fiscais nas décadas de 50, 60 e 70 concedidos aos produtores de trigo que beneficiaram identicamente a cultura da soja.

Anualmente a indústria nacional transforma em média 30,7 milhões de toneladas de soja, contribuindo para a concorrência nacional no cultivo de carnes, ovos e leite. A soja também é uma alternativa para a produção do biodiesel, 
combustível capaz de diminuir a emissão dos gases causadores do efeito estufa.

\section{Material e métodos}

Para a realização da pesquisa foi utilizado as informações repassadas pelo departamento administrativo Valter Santana Rebouças, através destas informações foi utilizada métodos de custeio direto e indireto que será demonstrado com clareza nas tabelas a seguir.

\section{Pesquisa de Campo}

A pesquisa tem como objetivo demonstrar o processo de trabalho e normas que é necessário seguir para conhecer o funcionamento de um arrendamento de terra para a produção de soja e feijão e estudar a viabilidade financeira de ambas culturas. A pesquisa foi realizada na propriedade arrendada por Valter Santana Rebouças localizada na Rodovia GO 173 km 48 Faz. Guanabara, com informações repassadas pelo seu departamento administrativo.

Tabelas de custos da Produção de Feijão

Tabela 1 - Produtos utilizados para o preparo do solo (210 Hectares)

\begin{tabular}{|c|c|c|c|}
\hline \multicolumn{3}{|l|}{ Arrendamento } & \multirow{2}{*}{$\begin{array}{l}\mathrm{R} \$ 140.000,00 \\
\mathrm{R} \$ 99.600,00\end{array}$} \\
\hline \multicolumn{3}{|l|}{ Fertilizantes } & \\
\hline Produto & Quantidade & Valor Unit. & Valor Total \\
\hline Gramoxene & 209,00 & $\mathrm{R} \$ 15,00$ & $\mathrm{R} \$ 3.135,00$ \\
\hline $2,4-\mathrm{D}$ & 206,00 & $\mathrm{R} \$ 11,00$ & $\mathrm{R} \$ 2.266,00$ \\
\hline Zapp QI & 425,00 & $\mathrm{R} \$ 15,00$ & RS $6.375,00$ \\
\hline Triton & 210,00 & $\mathrm{R} \$ 50,00$ & $\mathrm{R} \$ 10.500,00$ \\
\hline Stara & 210,00 & $\mathrm{R} \$ 120,00$ & $\mathrm{R} \$ 25.200,00$ \\
\hline Calcário FJ & 210,00 ton & $\mathrm{R} \$ 90,00$ & $\mathrm{R} \$ 18.900,00$ \\
\hline Distribuição calcário & 210,00 & $\mathrm{R} \$ 25,00$ & $\mathrm{R} \$ 5.250,00$ \\
\hline Milheto SMT & 4.000 & $\mathrm{R} \$ 0,80$ & $\mathrm{R} \$ 3.200,00$ \\
\hline Dist. Milheto & 210,00 & $\mathrm{R} \$ 20,00$ & $\mathrm{R} \$ 4.200,00$ \\
\hline Pulverização & 210,00 & $\mathrm{R} \$ 15,00$ & $\mathrm{R} \$ 3.150,00$ \\
\hline Maxin XL & 18,7 & $\mathrm{R} \$ 66,00$ & $\mathrm{R} \$ 1.234,20$ \\
\hline Larvin & 26,9 & $\mathrm{R} \$ 130,00$ & $\mathrm{R} \$ 3.497,00$ \\
\hline Nuprid & 6,3 & $\mathrm{R} \$ 85,00$ & $\mathrm{R} \$ 535,50$ \\
\hline Graffite & 20,00 & $\mathrm{R} \$ 2,00$ & $\mathrm{R} \$ 40,00$ \\
\hline Semente Feijão & $12.458,00$ & $\mathrm{R} \$ 3,50$ & $\mathrm{R} \$ 43.603,00$ \\
\hline Plantadeira & 210,00 & $\mathrm{R} \$ 120,00$ & $\mathrm{R} \$ 25.200,00$ \\
\hline Mao de Obra (chapa) & 288,00 & $\mathrm{R} \$ 15,00$ & $\mathrm{R} \$ 4.320,00$ \\
\hline \multicolumn{3}{|c|}{ Custo total no preparo do solo cultura de feijão } & $\mathrm{R} \$ 400.205,70$ \\
\hline
\end{tabular}

Fonte: Departamento Administrativo Valter Santana Rebouças

A pesquisa vem demonstrar um comparativo entre a produção de soja e feijão, na região vale do Araguaia em uma área reduzida em 210 hectares que equivale a $2.100 .000 \mathrm{~m}^{2}$ (dois milhões de metros quadrados), com objetivo de demonstrar os dados de uma forma clara, para que possa entender melhor a relação dos altos valores envolvidos, na manutenção de um modo geral. 
Tabela 1.2- Produtos utilizados com manutenção da lavoura de feijão

\begin{tabular}{|c|c|c|c|}
\hline Produto/Peças & Quantidade & Valor Unit. & Valor Total \\
\hline Contadora 220 VOLT & 1 & $\mathrm{R} \$ 106,00$ & $\mathrm{R} \$ 106,00$ \\
\hline Junta Universal & 5 & $\mathrm{R} \$ 73,00$ & $\mathrm{R} \$ 365,00$ \\
\hline Fazível NH2 80ª & 4 & $\mathrm{R} \$ 18,00$ & $\mathrm{R} \$ 72,00$ \\
\hline Coroa redutora de roda & 6 & $\mathrm{R} \$ 150,00$ & $\mathrm{R} \$ 900,00$ \\
\hline Sem fim redutora de roda & 5 & $\mathrm{R} \$ 150,00$ & $\mathrm{R} \$ 750,00$ \\
\hline Pneu 12-4-24 & 1 & $\mathrm{R} \$ 980,00$ & $\mathrm{R} \$ 980,00$ \\
\hline Câmara de ar 12-4-24 & 1 & $\mathrm{R} \$ 160,00$ & $\mathrm{R} \$ 160,00$ \\
\hline Rolamento 104949 & 4 & $\mathrm{R} \$ 64,50$ & $\mathrm{R} \$ 258,00$ \\
\hline Rolamento 387/382-A & 4 & $\mathrm{R} \$ 52,00$ & $\mathrm{R} \$ 208,00$ \\
\hline Anel de vedação 8 & 1 & $\mathrm{R} \$ 75,00$ & $\mathrm{R} \$ 75,00$ \\
\hline Retentor pq R. roda & 13 & $\mathrm{R} \$ 27,34$ & $\mathrm{R} \$ 355,42$ \\
\hline Retentor Gr R. roda & 8 & $\mathrm{R} \$ 68,67$ & $\mathrm{R} \$ 549,36$ \\
\hline Para-Raio & 2 & $\mathrm{R} \$ 200,00$ & $\mathrm{R} \$ 400,00$ \\
\hline Óleo 140 & 40,00 & $\mathrm{R} \$ 8,30$ & $\mathrm{R} \$ 332,00$ \\
\hline Óleo 68 & 20,00 & $\mathrm{R} \$ 7,30$ & $\mathrm{R} \$ 146,00$ \\
\hline Fuzilade & 104,50 & $\mathrm{R} \$ 45,00$ & $\mathrm{R} \$ 4.702,50$ \\
\hline Flex & 104,50 & $\mathrm{R} \$ 43,00$ & $\mathrm{R} \$ 4.493,50$ \\
\hline Amplico & 61,50 & $\mathrm{R} \$ 280,00$ & $\mathrm{R} \$ 17.220,00$ \\
\hline Diamante & 103,3 & $\mathrm{R} \$ 56,00$ & $\mathrm{R} \$ 5.784,80$ \\
\hline Supporte & 308,0 & $\mathrm{R} \$ 14,00$ & $\mathrm{R} \$ 4.312,00$ \\
\hline Priore xtra & 113,7 & $\mathrm{R} \$ 98,00$ & $\mathrm{R} \$ 11.142,60$ \\
\hline Certeiro & 21,0 & $\mathrm{R} \$ 90,00$ & $\mathrm{R} \$ 1.890,00$ \\
\hline Merlin & 61,5 & $\mathrm{R} \$ 95,00$ & $\mathrm{R} \$ 5.842,50$ \\
\hline Martch & 123,0 & $\mathrm{R} \$ 40,00$ & $\mathrm{R} \$ 4.920,00$ \\
\hline Pirate & 112,5 & $\mathrm{R} \$ 70,00$ & $\mathrm{R} \$ 7.875,00$ \\
\hline Supera & 102,5 & $\mathrm{R} \$ 24,60$ & $\mathrm{R} \$ 2.521,50$ \\
\hline Fastac & 103,3 & $\mathrm{R} \$ 25,00$ & $\mathrm{R} \$ 2.582,50$ \\
\hline Inex & 15,7 & $\mathrm{R} \$ 80,00$ & $\mathrm{R} \$ 1.256,00$ \\
\hline Nimbus & 104,5 & $\mathrm{R} \$ 8,00$ & $\mathrm{R} \$ 836,00$ \\
\hline Diamante-PO & 6,9 & $\mathrm{R} \$ 1.250,00$ & $\mathrm{R} \$ 8.625,00$ \\
\hline Pulverização (8*210) & 1.680 & $\mathrm{R} \$ 15,00$ & $\mathrm{R} \$ 25.200,00$ \\
\hline \multicolumn{3}{|l|}{ Alimentação de funcionário } & $\mathrm{R} \$ 3.080,08$ \\
\hline \multicolumn{3}{|l|}{ Agronômo } & $\mathrm{R} \$ 14.175,00$ \\
\hline \multicolumn{3}{|l|}{ Salário e ordenados } & $\mathrm{R} \$ 10.550,00$ \\
\hline \multicolumn{3}{|l|}{ Cleg Dist. S.A } & $\mathrm{R} \$ 69.582,72$ \\
\hline \multicolumn{3}{|l|}{ Fertilizantes - Aliança } & $\mathrm{R} \$ 149.400,00$ \\
\hline \multicolumn{3}{|c|}{ Custo total com manutenção da lavoura de feijão } & $\mathrm{R} \$ 361.648,48$ \\
\hline
\end{tabular}

Fonte: Departamento Administrativo Valter Santana Rebouças 
Por ser uma pesquisa com área total reduzida (área total 3.060 hectares, área da pesquisa 210 hectares), os custos direcionados a essa área são os custos diretos como peças e adubação, formam os custos diretos, e os custos que não são específicos apenas desta área como salários, foram rateados por hectares e direcionado a área da pesquisa.

Com relação à produção de soja, foi utilizada a variedade 98 e 12 fornecida pela empresa Pioneer, tal semente contêm características especiais para o mercado das regiões sojicultoras do centro do país, como alto potencial produtivo com ciclo precoce de 120 dias, apresentado no período de 15 de outubro de 2014 a 15 de fevereiro de 2015.

Com relação à produção de feijão foi utilizada a variedade CARIOCA (GOL), variedade nova no mercado, resistente a algumas doenças que afetam outras variedades, com ciclo de 75 dias, apresentado no período de 15 de abril de 2015 a 1 de julho de 2015. Ambas as culturas são temporárias e foram produzidas na mesma área, por meio do método de irrigação feita por pivô central.

Analisando a Tabela 1, notamos a relação dos custos utilizados para o processo de preparo do solo onde será plantada a lavoura de feijão.

Desde o início com o arrendamento da área de 210 hectares, passando pela limpeza da mesma, aração, adubação química e adubação orgânica, esta que foi realizada por meio da plantação de milheto, uma variedade de capim que é utilizado no plantio direto servindo como palhada. Após ser dessecado tal palhada foi utilizada para adubação e proteção do solo, após todo o processo de preparar e cuidar do solo acontece o momento do plantio das sementes de feijão.

Depois desde processo começa outra etapa que aborda a manutenção da lavoura que requer outros métodos de trabalho.

A Tabela 1.2 apresentou a questão do custo utilizado na manutenção da lavoura de feijão, pois após o processo de preparo do solo e sua manutenção vem agora a parte de cuidar desta semente que foi plantada. Parte essa que requer mais cuidado, a saber, podem acontecer vários fatores que prejudiquem a germinação e produção da mesma, fatores como pragas, falta de irrigação, pois, a saber, a lavoura é feita na área de pivô central e podem acontecer danos no mesmo que prejudica a irrigação, com isso atrasando e danificando a germinação.

O período do plantio tem aproximadamente 75 dias, durante o período á necessidade de cuidados que inicia com a irrigação, o combate e controle de pragas e doenças por meio da pulverização de fungicidas, e o controle dos insetos mediante o uso dos inseticidas. Ambos utilizados com objetivo de melhorar a produção e qualidade da lavoura, ao qual objetiva colher um produto com quantidade e qualidade.

Um fator que deve ser notado é a presença do agrônomo Zé Roberto de Meneses, que tem papel fundamental na produção com qualidade e quantidade, mostrando assim que mesmo sendo um produtor que está há anos na área rural e que tem um grande conhecimento, também necessita de alguém orientando-o para conseguir se manter no mercado e produzindo. Orientação essa de auxiliar com novas sementes e produtos de qualidade que estão surgindo no mercado alimentício.

Analisando as duas etapas anteriores percebese que o processo inicia com a preparação do solo e os cuidados com as sementes, partem para a etapa final que é a colheita da lavoura (Tabela $\underline{1.3}$ ).

Este processo é realizado em duas etapas, o primeiro constituiu na dessecagem das folhas, acelerando o processo de secagem das folhas para não manchar os grãos na colheita, o que pode prejudicar a qualidade do grão. A segunda etapa que é a colheita do grão, nessa colheita requer outros trabalho e cuidados, pois necessita de máquina adequada para realizar a colheita da semente. Não pode deixar o produto passar do tempo de colher, pois prejudica no processo de venda, a saber, caso a semente não esteja adequada com a procura, à mesma é devolvida para o dono da lavoura. Depois de colhido e descarregado nos caminhões e transportado para o comprador, à responsabilidade não é mais do produtor, e sim do corretor, que intermédia à compra do feijão.

O objetivo da Tabela 2 é mostrar que todos os $576.080,00$ quilos, que equivalem a 9.601,33 sacos de 60 quilos, que foram produzidos na respectiva área, foram vendidos para a empresa de corretagem Santa Fé grãos, com sede na cidade de Santa Fé de Goiás, que é o responsável pelo transporte e entrega do produto para a devida empresa, onde o produto será beneficiado. 
Tabela 1.3 - Produtos utilizados com a colheita da cultura do Feijão

\begin{tabular}{l|c|c|c}
\hline Produto/Maquinas & Quantidade & Valor Unit. & Valor Total \\
\hline Regrone & 627,00 & $\mathrm{R} \$ 15,00$ & $\mathrm{R} \$ 9.405,00$ \\
\hline Pulverização & 210 & $\mathrm{R} \$ 15,00$ & $\mathrm{R} \$ 3.150,00$ \\
\hline Colheitadeira Case & 210 & $\mathrm{R} \$ 310,00$ & $\mathrm{R} \$ 65.100,00$ \\
\hline Custo total com a colheita da cultura do Feijão & & $\mathrm{R} \$ 77.655 .00$ \\
\hline
\end{tabular}

Fonte: Departamento Administrativo Valter Santana Rebouças

Tabela 2- Receita de venda de Feijão

\begin{tabular}{l|c|c|c|c}
\hline Cliente & Peso Kg. & Qtdade Scs (60Kg.) & Valor P/ Sacos & Valor total \\
\hline Santa Fe Grãos & $576.080,00$ & $9.601,33$ & $\mathrm{R} \$ 135,00$ & $\mathrm{R} \$ 1.296 .179,55$ \\
\hline
\end{tabular}

Fonte: Departamento Administrativo Valter Santana Rebouças

O intuito da Tabela 3 é apresentar os gastos das despesas para a administração da lavoura de feijão, dentre despesas administrativas, de vendas e despesas bancarias do período em questão.

O propósito da Tabela 4 é demonstrar a soma de todos os gastos decorridos, no período da produção do feijão, iniciado no preparo do solo até o final da colheita, ou seja, no período aproximado de 75 dias, dos 9.601,33 sacos que foi a produção total.

A Tabela 4.1 demonstra a forma utilizada para se obter o custo especifico por hectares ocorridos durante a safra do feijão, que é feita pela divisão dos custos totais da produção de feijão, pela área total produzida, obtendo assim o custo por Hectares.

Tem por objetivo a Tabela 4.2 de especificar a quantidade média de sacas que foram produzidas por hectares. Através do cálculo utilizando as sacas produzidas na área total dividida pela área, assim obtendo a produção por hectare, em sacas.

O objetivo da Tabela 4.3 é demonstrar a elaboração dos cálculos para descobrir o custo por sacas da colheita, por meio da divisão entre o custo da produção por hectare, pela quantidade de sacas produzidas por hectare, obtendo assim o CPV (custo produto vendido) por sacas no valor de $\mathrm{R} \$ 87,44$.

Tabela 3 - Despesas durante a safra

Despesas administrativas

$\mathrm{R} \$ 27.186,83$

Fonte: Departamento Administrativo Valter Santana Rebouças

Tabela 4-Custo total da produção de feijão (210 Hectares)

\begin{tabular}{l|r}
\hline Preparo do solo (210 Hectares) & $\mathrm{R} \$ 400.205,70$ \\
\hline Custo com manutenção da lavoura de feijão & $\mathrm{R} \$ 361.648,48$ \\
\hline Custo com a colheita da cultura do Feijão & $\mathrm{R} \$ 77.655,00$ \\
\hline Total & $\mathrm{R} \$ 839.509,18$ \\
\hline Produção total em sacas (60 Kg.) & $9.601,33$ \\
\hline
\end{tabular}

Fonte: Departamento Administrativo Valter Santana Rebouças.

Tabela 4.1-Custo da produção de feijão por hectare

\begin{tabular}{l|r}
\hline Custo total da produção de feijão & R\$ 839.509,18 \\
\hline Área Produzida & 210 há \\
\hline Total do custo por Hectares & R\$ 3.997,66 \\
\hline
\end{tabular}

Fonte: Departamento Administrativo Valter Santana Rebouças 
Tabela 4.2 - Produção em sacas por hectare

\begin{tabular}{l|r}
\hline Total de sacas produzidas & $9.601,33$ \\
\hline Área produzida & 210 \\
\hline Total de sacas por hectare & 45,72 sacas \\
\hline
\end{tabular}

Fonte: Departamento Administrativo Valter Santana Rebouças

Tabela 4.3-Custo da produção por sacas $60 \mathrm{Kg}$.

\begin{tabular}{l|r}
\hline Custo por Hectare & $\mathrm{R} \$ 3.997,66$ \\
\hline Sacas por Hectare & 45,72 \\
\hline $\mathrm{CPV}^{1}$ unitário sacas & $\mathrm{R} \$ 87,44$ \\
\hline
\end{tabular}

${ }^{\mathrm{I}} \mathrm{CPV}$ : Custo produto vendido; Fonte: Departamento Administrativo Valter Santana Rebouças

Na Tabela 5 consta o resultado do exercício, da produção de feijão. Através disto podemos observar que houve um lucro operacional de

$35,23 \%$ com relação a receita de vendas, e os $64,77 \%$ restante equivale ao custo do produto vendido

Tabela 5-Resultado do exercício

\begin{tabular}{l|r}
\hline Receita & $\mathrm{R} \$ 1.296 .179,55$ \\
\hline ( - ) CPV & $(\mathrm{R} \$ 839.539,18)$ \\
\hline ( = ) Receita operacional & $\mathrm{R} \$ 456.670,37$ \\
\hline ( - ) Despesas & $(\mathrm{R} \$ 35.186,83)$ \\
\hline ( = ) Resultado do exercício & $\mathrm{R} \$ 429.483,62$
\end{tabular}

${ }^{1} \mathrm{CPV}$ : Custo produto vendido; Fonte: Departamento Administrativo Valter Santana Rebouças

Tabelas de custos da Produção de Soja

Estão relacionados na Tabela 6 todos os custos e produtos agrícolas, que foram utilizados para o processo de preparo do solo, desde o início com o arrendamento da área de 210 hectares, passando pela limpeza da mesma, arado e adubação química. Depois desse processo começa outra etapa que aborda a manutenção da lavoura que requer outros métodos de trabalho.

Tabela 6- Produtos utilizados no preparo do solo (210 Hectares)

\begin{tabular}{|c|c|c|c|}
\hline \multicolumn{3}{|l|}{ Arredamento } & $\mathrm{R} \$ 100.000,00$ \\
\hline \multicolumn{3}{|c|}{ Fertilizante - Aliança } & $\mathrm{R} \$ 21.727,19$ \\
\hline Produto & Quantidade & Valor Unit. & Valor Total \\
\hline Pulverização & 210,00 & $\mathrm{R} \$ 15,00$ & $\mathrm{R} \$ 3.150,00$ \\
\hline Nivelador Trator & 210,00 & $\mathrm{R} \$ 100,00$ & $\mathrm{R} \$ 21.000,00$ \\
\hline Zapp QI & 377,5 & $\mathrm{R} \$ 15,00$ & $\mathrm{R} \$ 5.662,50$ \\
\hline Desc.fert.chapa & 5 & $\mathrm{R} \$ 15,00$ & $\mathrm{R} \$ 75,00$ \\
\hline Grafite & 20,00 & $\mathrm{R} \$ 2,00$ & $\mathrm{R} \$ 40,00$ \\
\hline Semente soja & $10.158,00$ & $\mathrm{R} \$ 4,66$ & $\mathrm{R} \$ 47.336,28$ \\
\hline Plantadeira & 210,00 & $\mathrm{R} \$ 120,00$ & $\mathrm{R} \$ 25.200,00$ \\
\hline \multicolumn{3}{|c|}{ TOTAL } & $\mathrm{R} \$ 224.190,97$ \\
\hline
\end{tabular}

Fonte: Departamento Administrativo Valter Santana Rebouças 
$\mathrm{Na}$ Tabela 6.1 expressa a questão do custo e produtos utilizados na manutenção da lavoura de soja, pois após o processo de preparo do solo e suas manutenções, vem agora a parte de cuidar desta semente que foi plantada. Essa parte que requer mais cuidado, a saber, podem acontecer vários fatores que prejudique a germinação e produção da mesma, fatores esses como pragas.
O período do plantio tem aproximadamente 120 dias, durante o período necessita de cuidados que inicia com a irrigação, o combate e controle de pragas e doenças por meio da pulverização de fungicidas e o controle dos insetos mediante $o$ uso dos inseticidas. Ambos utilizados com objetivo de melhorar a produção e qualidade da lavoura, ao qual objetiva colher um produto com quantidade e qualidade.

Tabela 6.1- Produtos utilizados com manutenção da lavoura de Soja

\begin{tabular}{|c|c|c|c|}
\hline \multicolumn{3}{|c|}{ Fertilizantes - Alianças } & \multirow{2}{*}{$\frac{\mathrm{R} \$ 32.590,78}{\text { Valor Total }}$} \\
\hline Produto/Peças & Quantidade & Valor Unit. & \\
\hline Cantoneira3/16x 2" & 5 & 126,00 & $\mathrm{R} \$ 630,00$ \\
\hline Cantoneira3/16x 2" & 3 & 108,67 & $\mathrm{R} \$ 326,01$ \\
\hline Cad. Lavoura & 208 & 0,50 & $\mathrm{R} \$ 104,00$ \\
\hline Pulverização & $1.520,00$ & 15,00 & $\mathrm{R} \$ 22.800,00$ \\
\hline Inoculante ds & 410,00 & 1,80 & $\mathrm{R} \$ 738,00$ \\
\hline Larvin & 10,3 & 135,00 & $\mathrm{R} \$ 1.390,50$ \\
\hline Supporte & 20,5 & 14,00 & $\mathrm{R} \$ 287,00$ \\
\hline Maxin XL & 10,3 & 66,00 & $\mathrm{R} \$ 679,80$ \\
\hline Pirate & 101,2 & 70,00 & $\mathrm{R} \$ 7.084,00$ \\
\hline Certeiro & 111,4 & 90,00 & $\mathrm{R} \$ 10.026,00$ \\
\hline Fastac & 195,0 & 23,00 & $\mathrm{R} \$ 4.485,00$ \\
\hline Iharol & 10,00 & 6,00 & $\mathrm{R} \$ 60,00$ \\
\hline Amplico & 25,5 & 280,00 & $\mathrm{R} \$ 7.140,00$ \\
\hline Rotamik & 26,9 & 17,00 & $\mathrm{R} \$ 457,30$ \\
\hline Manganês & 209,0 & 6,00 & $\mathrm{R} \$ 1.254,00$ \\
\hline Nuprid & 113,8 & 80,00 & $\mathrm{R} \$ 9.104,00$ \\
\hline Priore xtra & 124,5 & 96,00 & $\mathrm{R} \$ 11.952,00$ \\
\hline Celeiro & 62,0 & 36,00 & $\mathrm{R} \$ 2.232,00$ \\
\hline Agua Best & $2.985,0$ & 0,30 & $\mathrm{R} \$ 895,50$ \\
\hline Best & 25,0 & 70,00 & $\mathrm{R} \$ 1.750,00$ \\
\hline Celeiro & 30,0 & 36,00 & $\mathrm{R} \$ 1.080,00$ \\
\hline \multicolumn{3}{|l|}{ Agrônomo } & $\mathrm{R} \$ 11.130,00$ \\
\hline \multicolumn{3}{|c|}{ Alimentação de funcionário } & $\mathrm{R} \$ 3.430,28$ \\
\hline \multicolumn{3}{|l|}{ Salários e ordenados } & $\mathrm{R} \$ 7.066,00$ \\
\hline \multicolumn{3}{|l|}{ Celg Dist. S.A } & $\mathrm{R} \$ 38.227,21$ \\
\hline \multicolumn{3}{|l|}{ Total } & $\mathrm{R} \$ 176.919,38$ \\
\hline
\end{tabular}

Fonte: Departamento Administrativo Valter Santana Rebouças 
Um fator importante assim como na cultura de feijão, na soja também a necessidade da presença ativa do agrônomo Zé Roberto de Meneses, com papel na produção tanto na questão de qualidades quanto de quantidade, mostrando como foi citado antes mesmo sendo um agricultor que está no ramo há anos, necessitando de alguém para ser orientado e conseguindo assim se manter no mercado e produzindo. Notamos que os cuidados e manejos são semelhantes aos do feijão, tanto no preparo do solo como na maneira do plantio, com a orientação do mesmo agrônomo, que trabalha com as duas sementes.

Após as duas etapas anteriores que inicia com a preparação do solo e os cuidados com as sementes, partem para a etapa final que é a colheita da lavoura (Tabela 6.2).

Este processo é realizado em duas etapas, primeiro constituem na secagem das folhas, como por exemplo, acelerarem o processo de secagem das folhas para não manchar os grãos na colheita, prejudicando assim a qualidade do produto para que possa em seguida passar para a segunda etapa que é a colheita do produto, onde depois de colhido e descarregado nos caminhões é transportado para o comprador.

Todos os 781.578,00 quilos, que equivalem a 13.026,30 sacos de 60 quilos, que foram produzidos na respectiva área, foram vendidos para a empresa COMIGO - Cooperativa Agroindustrial dos Produtores Rurais dos Sudoeste Goiano, com sede na cidade de Montes Claros de Goiás, onde o produto colhido foi entregue diretamente no depósito da empresa (Tabela 7).

A Tabela 8 está relacionada com as despesas para a administração bancária e de vendas da lavoura, despesas essas incorridas no período do plantio da soja.

Tabela 6.2- Produtos utilizados com a colheita da cultura da Soja

\begin{tabular}{l|c|c|c}
\hline Produto/Maquinas & Quant. & Valor unit. & Valor total \\
\hline Pulverização & 210,00 & $\mathrm{R} \$ 15,00$ & $\mathrm{R} \$ 3.150,00$ \\
\hline Regrone & 150,00 & $\mathrm{R} \$ 15,00$ & $\mathrm{R} \$ 2.250,00$ \\
\hline Colheitadeira Case & 210,00 & $\mathrm{R} \$ 180,00$ & $\mathrm{R} \$ 37.800,00$ \\
\hline Transportes & $13.364,40$ & $\mathrm{R} \$ 2,30$ & $\mathrm{R} \$ 30.738,12$ \\
\hline
\end{tabular}

Fonte: Departamento Administrativo Valter Santana Rebouças

Tabela 7- Receita de venda de Soja

\begin{tabular}{l|c|c|c|c}
\hline Cliente & Peso Kg. & Qtdade Scs(60Kg.) & Valor P/ Sacos & Valor total \\
\hline COMIGO/montes claros & $781.578,00$ & $13.026,3$ & $\mathrm{R} \$ 53,00$ & $\mathrm{R} \$ 690.393,90$ \\
\hline
\end{tabular}

Fonte: Departamento Administrativo Valter Santana Rebouças

Tabela 8- Despesas durante a safra

Despesas administrativas

$\mathrm{R} \$ 20.373,72$

Fonte: Departamento Administrativo Valter Santana Rebouças

A soma dos gastos decorridos no período da produção da soja, iniciado no preparo do solo até o final da colheita, ou seja, no período aproximado de 120 dias, dos 13.026,30 sacos que foi a produção total (Tabela 9)

Na Tabela 10 está demonstrada a forma utilizada para se obter o custo especifico por hectares ocorridos durante a safra da soja, que é calculada pela divisão dos custos totais da produção da soja pela área total produzida, obtendo assim o custo por hectares.

A quantidade média de sacas que foram produzidas por hectares. Utilizando o cálculo das sacas produzidas na área total dividida pela área, assim obtendo a produção por hectare, em sacas está especificado na Tabela 10.1.

A Tabela 10.2 demonstra a elaboração dos cálculos para descobrir o custo por sacas da 
colheita, por meio da divisão entre o custo da produção por hectare, pela quantidade de sacas produzidas por hectare, obtendo assim o CPV por sacas no valor de $\mathrm{R} \$ 36,47$

Tabela 9- Custo total da produção de soja (210 Hectares)

\begin{tabular}{l|r}
\hline Preparo do solo (210 Hectares) & $\mathrm{R} \$ 224.190,97$ \\
\hline Custo com manutenção da lavoura de soja & $\mathrm{R} \$ 176.919,38$ \\
\hline Custo com a colheita da cultura da soja & $\mathrm{R} \$ 73.938,12$ \\
\hline TOTAL & $\mathrm{R} \$ 475.048,47$ \\
\hline Produção total em sacas (60 Kg.) & $13.026,30$ \\
\hline
\end{tabular}

Fonte: Departamento Administrativo Valter Santana Rebouças

Tabela 10- Custo da produção de soja por hectare

\begin{tabular}{l|r}
\hline Custo total da produção de soja & $475.048,47$ \\
\hline Área Produzida & 210 ha \\
\hline Total do custo por Hectares & $\mathrm{R} \$ 2.262,14$ \\
\hline
\end{tabular}

Fonte: Departamento Administrativo Valter Santana Rebouças

Tabela 10.1-Produção em sacas por hectare

\begin{tabular}{l|r}
\hline Total de sacas produzidas & $13.026,30$ \\
\hline Área produzida & 210 ha \\
\hline Total de sacas por hectare & 62,03 sacas \\
\hline
\end{tabular}

Fonte: Departamento Administrativo Valter Santana Rebouças

Tabela 10.2- Custo da produção por sacas $60 \mathrm{Kg}$.

\begin{tabular}{l|r}
\hline Custo por Hectare & $\mathrm{R} \$ 2.262,14$ \\
\hline Sacas por Hectare & 62,03 sacas \\
\hline $\mathrm{CPV}^{1}$ unitário sacas & $\mathrm{R} \$ 36,47$ \\
\hline
\end{tabular}

${ }^{\mathrm{T}} \mathrm{CPV}$ : Custo produto vendido; Fonte: Departamento Administrativo Valter Santana Rebouças

Na Tabela 11 demonstra o resultado do exercício, da produção de soja. Podemos observar que houve um lucro operacional de
$31,19 \%$ com relação a receita de vendas, e os $68,81 \%$ restantes equivale ao custo do produto vendido.

Tabela 11-Resultado do exercício

\begin{tabular}{l|r}
\hline Receita & $\mathrm{R} \$ 690.393,90$ \\
\hline ( - ) CPV & $(\mathrm{R} \$ 475.048,19)$ \\
\hline ( = ) Receita operacional & $\mathrm{R} \$ 215.345,71$ \\
\hline ( - ) Despesas & $(\mathrm{R} \$ 20.373,72)$ \\
\hline ( = ) Resultado do exercício & $\mathrm{R} \$ 194.971,99$ \\
\hline
\end{tabular}

${ }^{1} \mathrm{CPV}$ : Custo produto vendido; Fonte: Departamento Administrativo Valter Santana Rebouças 
Tabelas de comparativo entre as culturas

Tabela 12- Comparativo dos custos

\begin{tabular}{l|c|c|c}
\hline & Feijão & Soja & Variação (\%) \\
\hline Preparo do solo & $\mathrm{R} \$ 400.205,70$ & $\mathrm{R} \$ 224.190,97$ & 43,98 \\
\hline $\begin{array}{l}\text { Custo com manutenção da } \\
\text { lavoura de feijão }\end{array}$ & $\mathrm{R} \$ 361.648,48$ & $\mathrm{R} \$ 176.919,38$ & 51,08 \\
\hline Com a colheita da cultura & $\mathrm{R} \$ 77.655,00$ & $\mathrm{R} \$ 73.938,18$ & 4,79 \\
\hline Total & $\mathrm{R} \$ 839.509,18$ & $\mathrm{R} \$ 475.048,47$ & 43,41 \\
\hline
\end{tabular}

Fonte: Departamento Administrativo Valter Santana Rebouças

Através da Tabela 12 pode se observar que a cultura do feijão requer maior gastos e atenção nas etapas de preparo do solo e na manutenção da lavoura, pois é uma cultura mais exigente de atenção, para que se possa obter o máximo de produção e qualidade.
$\mathrm{Na}$ etapa do preparo a cultura da soja teve um gasto de aproximadamente $43,98 \%$ menor em relação a de feijão, já na etapa de manutenção da lavoura a diferença foi ainda maior de aproximadamente $51,08 \%$ menor, já na colheita a diferença já foi menor sendo de aproximadamente $4,79 \%$.

Tabela 13- Comparativo receita operacional (210 Hectare)

\begin{tabular}{l|c|c|c}
\hline & Feijão & Soja & Variação $(\%)$ \\
\hline Receita & R\$ $1.296 .179,55$ & R \$ 690.393,90 & 53,26 \\
\hline Custos & R\$ 839.509,18 & R \$ 475.048,47 & 43,41 \\
\hline Produção em sacas & $9.601,33$ & $13.026,30$ & 35,67 \\
\hline Receita operacional & $\mathrm{R} \$ 456.670,37$ & $\mathrm{R} \$ 215.345,71$ & 47,15 \\
\hline
\end{tabular}

Fonte: Departamento Administrativo Valter Santana Rebouças

A análise na Tabela 13 da variação entre os dados obtidos na pesquisa de campo, percebe-se que mesmo, a produção da soja tendo um custo de apenas $43,41 \%$ do que foi gasto com o feijão e mesmo que a produção tenha sido $35,67 \%$ maior, a receita operacional do feijão consegue ser $47,15 \%$ maior do que a soja.

Como visto na Tabela 14, mesmo a produção de soja sendo maior e com um custo menor do que a de feijão, a receita da produção de feijão é maior, os motivos ficam evidentes na Tabela 2 , onde mostra o preço de venda do feijão por saca foi $60,74 \%$ maior, o que equivale a $\mathrm{R} \$ 82,00$.

Com todos esses fatores de preços, obtivemos uma receita por unidade de $\mathrm{R} \$ 47,56$ para o feijão e R\$ 16,53 para a soja, o que explica porque mesmo a soja tendo uma produção maior e um custo menor, não consegue ter uma receita maior que a do feijão, onde a uma variação de $65,24 \%$ no valor da recita operacional por saca, o que equivale a $\mathrm{R} \$ 31,03$.

Tabela 14- Comparativo por sacas $(60 \mathrm{Kg})$

\begin{tabular}{l|c|c|c}
\hline & Feijão & Soja & Variação (\%) \\
\hline Preço da saca & $\mathrm{R} \$ 135,00$ & $\mathrm{R} \$ 53,00$ & 60,74 \\
\hline Custos & $\mathrm{R} \$ 87,44$ & $\mathrm{R} \$ 36,47$ & 58,29 \\
\hline Receita operacional & $\mathrm{R} \$ 47,56$ & 16,53 & 65,24 \\
\hline
\end{tabular}

Fonte: Departamento Administrativo Valter Santana Rebouças. 


\section{Conclusão sobre a pesquisa de campo}

Após a observação detalhada dos dados sobre a produção de soja e feijão e seus valores, conclui-se que a produção de feijão é mais lucrativa em relação a soja, além de ser realizada em um período menor de tempo.

Observando essas informações pode se questionar "porque então não se fazer dois ou até três safras de feijão no ano?" a resposta é simples economicamente e inviável, a cultura do feijão exige muito do solo, causando algumas doenças deixando o solo fraco e ácido. De acordo com depoimento de pessoas que trabalham com plantio de leguminosas, já foi testado esse manejo com duas safras de feijão no mesmo ano, sendo no primeiro ano o solo suporta esse tipo de manejo, já no segundo ano não teve uma mesma produção, já no terceiro ano não produzia nada, então o solo necessita de um descanso para continuar produzindo.

Com o plantio da mesma lavoura diversas vezes no solo, o mesmo perde muitos nutrientes, tendo assim que repor com produtos que prejudica ainda mais o solo, desta forma utilizase a rotação de cultura, pois o solo consegue repor os nutrientes perdidos.

Devemos ressaltar a questão do risco, as informações colhidas na pesquisa de campo foram de safras com produção de qualidade, e com valor de venda positiva em ambas as culturas, mas há sempre um risco o que influência no valor de venda. Com relação ao risco o feijão é maior, pois é uma cultura de consumo $100 \%$ interno, então a variação no preço é alta, podendo variar $R \$ 10,00$ ou mais em questão de 24 horas, ocorrendo o fator da oferta e demanda, pode ter muito feijão no mercado e preço baixo, pouco feijão no mercado e preço alto.

Com a soja o risco é menor, pois se vendida a soja em grãos plantados, por meio do contrato futuro, onde o preço é estabelecido e o prazo de entrega definido, assim iremos trabalhar sabendo quanto vou ganhar e quando devo entregar o produto, sem correr risco. Com a soja não acontece à variação de preço, como ocorre na produção do feijão.

\section{Conclusão}

Fazer um estudo de comparação entre dois produtos agrícolas de grande peso na mesa especialmente do brasileiro não é uma tarefa fácil. Porém nosso estudo reteve-se em confrontar as despesas e lucros para então auferir qual dos dois seria de maior vantagem para os produtores da nossa região. Para alcançarmos os objetivos propostos foi necessário entender desde o início da contabilidade rural, onde desde a préhistória nossos ancestrais já encontraram uma forma de contabilizar seus rebanhos e que com o passar dos tempos só tiveram avanços até chegar hoje na ciência que estamos estudando, a contabilidade.

Podemos perceber que a maior evolução só aconteceu na Idade Moderna, mais precisamente no Renascimento, com os grandes impactos das outras ciências sobre esta, até a Arte teve seu papel influenciador na Ciência Contábil. A partir daí a contabilidade esteve cada vez mais presente na vida e nos negócios dos empresários, fossem eles industriários ou fazendeiros sendo estes nas áreas agrícolas ou na pecuária, deixando então de ser um mero serviço de prestação de informação e passando então a fazer parte nas tomadas de decisões de praticamente todos os ramos de negócios.

No Brasil esta influência só foi marcante no início do século XIX pela escola Italiana com a fundação da primeira Faculdade de Ciências Econômicas e Administrativas da Universidade se São Paulo-USP. Portanto como percebemos, ainda não é uma faculdade voltada apenas para os interesses contábeis, mas sim administrativos, sendo estes dois caminhos que andam juntos. Apenas na década de 60 que alavancamos mais um pouco, onde sobre a influência dos Estados Unidos tivemos um estudo voltado para a metodologia da contabilidade.

Partindo para a contabilidade rural podemos observar que mesmo sendo este um riquíssimo instrumento para o produtor rural, ainda é bastante grande o número de pecuaristas e agricultores que não possui este tipo de acompanhamento em sua propriedade, o que faz com que muitas vezes perca o controle da situação. Apenas nas grandes propriedades onde há um contingente maior de trabalhadores e principalmente nas áreas de cultivo de grãos é que esta ciência está sendo mais bem aceita e colocada em prática.

E ao realizarmos esta pesquisa de comparação podemos perceber o quão grande é a importância da contabilidade na vida desses agricultores, pois é ela quem irá orientar as entradas e saídas, ou seja, despesas e lucros dos empresários rurais, lembrando aqui que esta também é uma empresa 
e é a partir destes dados que a empresa tomará as decisões para todas as safras do ano, onde conhecendo ganhos e gastos poderá investir melhor no ramo que mais gerará renda com menores despesas. Vale ressaltar aqui que nem sempre o melhor é aquele em que o mercado oferece maior valor de compra, pois as despesas devem ser comparadas no saldo final.

Atividade agrícola vegetal temporária é aquela que trabalha com safras e colheitas dentro de um determinado período de tempo sendo a plantação arrancada para que outra safra venha ocupar aquele lugar. Dessa forma podemos analisar a safra do feijão e da soja na nossa região, onde percebemos que o plantio do feijão requer tanto cuidado quanto o da soja, como preparação de terreno, adubação, maquinário e recursos humanos. As duas lavouras aqui analisadas requer um clima de temperatura não muito quente e tampouco muito frio, nem muita chuva e nem seca intensa, por isso há o cultivo de forma irrigada com os conhecidos pivô central que jorram água no período da estiagem sobre as lavouras.

A cultura da soja é a que mais tem crescido no país nas últimas três décadas, mas na nossa região apenas há pouco tempo vem sendo praticada de forma mais intensa, o que ainda prevalece aqui na região é o cultivo do feijão.

Contudo, levando em consideração a análise realizada a partir da pesquisa, percebemos que, partindo de todas as formas de despesas até a venda do produto, seja a soja ou o feijão, ainda é mais compensativo na região o cultivo do feijão, pois mesmo a soja tendo uma maior produção por hectare, o feijão tem uma receita operacional mais satisfatória e uma variação menor no mercado financeiro, o que torna então o feijão, como supracitado, o campeão de produção na região de Jussara.

\section{Referências Bibliográficas}

Araújo, M. J. (2007). Fundamentos de agronegócios. Ed atlas $2^{a}$ Ed. São Paulo.

Crepaldi, S. A. (1998). Contabilidade Rural, 2. ed. São Paulo: Atlas.

Crepaldi, S. A. (2004). Contabilidade Empresarial, 10. Ed. São Paulo: Atlas.

Crepaldi, S. A. (2005). Contabilidade Rural, 3. Ed. São Paulo: Atlas.
Crepaldi, S. A. (2012). Contabilidade Rural, Ed atlas $7^{\mathrm{a}}$ Ed São Paulo.

Departamento técnico agrícola. Feijão do plantio a colheita Quimbrasil Março de 1985. Departamento Administrativo Valter Santana Rebouças - Fazenda Guanabara, Rodovia GO $173 \mathrm{Km} \mathrm{48}$, Santa Fé de Goiás Go, Agosto 2015.

Gomes, A. (1997). Contabilidade Rural e agricultura familiar. Rondonópolis: Gráfica União.

Iudícibus, S. \& Marion, J, C. (2002). Introdução à teoria da Contabilidade para o nível de graduação. $3^{\mathrm{a}}$. Ed. São Paulo: Atlas.

Iudícibus, S. \& Marion, J.C. (2006). Introdução à teoria da contabilidade para o nível de graduação. $4^{a}$. Ed. São Paulo: Atlas.

Iudícibus, S. (2006). Teoria da Contabilidade. $8^{\mathrm{a}}$. Ed. São Paulo: Atlas.

Marion, J. C. (2002). Contabilidade Rural. Ed atlas $7^{\mathrm{a}}$ Ed São Paulo.

Marion, J. C. (2003). Contabilidade empresarial. $10^{a}$ Ed. São Paulo: Atlas.

Marion, J. C. (2005). Contabilidade empresarial. $10^{\mathrm{a}}$ Ed. São Paulo: Atlas.

Nagatsuka, D. A. \& Teles E. L. (2002). Manual de Contabilidade Introdutória. São Paulo: Pioneira Thomson Learning.

Neves, M. F. (2007). Agronegócios e desenvolvimento sustentável. Ed atlas S.A $1^{\text {a }}$ Ed. São Paulo.

Niyama, J. K. (2013). Teoria da contabilidade, Ed. Atlas 3 Ed. São Paulo.

Reis, J. N. P. (2006). Desempenho comercial da agricultura brasileira: os casos do feijão e do milho. Informações Econômicas, 36, 20-28.

Silveira, M. A., Johann, A. R. G., Wander, A. E. \& Campos, W. P. (2014). Estratégias de comercialização do feijão produzido por Agricultores Familiares: Um estudo de caso na região leste do estado de Goiás. Instituto Mario Borges de estatísticas e estudos socioeconômicos série n 30 .

Recebido em Janeiro11, 2016

Aceito em Fevereiro 11, 2016

License information: This is an open-access article distributed under the terms of the Creative Commons Attribution License, which permits unrestricted use, distribution, and reproduction in any medium, provided the original work is properly cited 
Anexo 1.

\section{CONTRATO DE ARRENDAMENTO RURAL (modelo simples)}

Pelo presente contrato particular de arrendamento rural, feito e ajustado entre as partes abaixo assinadas, de um lado, como arrendante, o Senhor (qualificação completa e endereço), de ora em diante chamado apenas ARRENDANTE; e do outro lado, como arrendatário, o Senhor___(idem)_, de ora em diante chamado apenas ARRENDATÁRIO, têm entre si justo e contratado o arrendamento de um imóvel rural, mediante as condições fixadas nas cláusulas seguintes: CLÁUSULA PRIMEIRA - O arrendante é proprietário de um imóvel rural denominado "Fazenda Cascata" no município de Estado conforme escritura lavrada no Cartório de Registro de imóveis da Comarca de sob a matrícula $\mathrm{n}^{\circ}$ e Cadastro no Incra $n^{\circ}$ conforme

Certificado de Cadastro que segue em anexo a este contrato para fins de registro. E, nessa condição, resolve arrendar uma parte (ou a totalidade) do referido imóvel ao Arrendatário nas condições estabelecidas nas cláusulas subsequentes.

Se o arrendamento for apenas de parte do imóvel, descrever a área a ser arrendada.

Caso entrem casas e outras benfeitorias, esclarecer.

CLÁUSULA SEGUNDA - A área ora arrendada destina-se ao plantio de o Arrendatário mudar a sua destinação sem o prévio consentimento por escrito do Arrendante.

CLÁUSULA TERCEIRA - O prazo de duração do arrendamento é de anos, a iniciar-se no dia , não podendo mês do ano de e a terminar no dia data em que o Arrendatário se compromete a devolver o imóvel livre e desocupado de pessoas e coisas, na forma que o recebeu.

CLÁUSULA QUARTA - Caso haja interesse das partes, por ocasião de seu término, este contrato poderá ser renovado pelo período que lhes convier e mediante as condições que pactuarem desde que a parte interessada notifique a outra dentro do prazo legal.

CLÁUSULA QUINTA - O preço do arrendamento é de R\$ e será pago da seguinte forma: (fixar o preco e as condicões de pagamento)

CLÁUSULA SEXTA - Os impostos e taxas incidentes sobre a gleba arrendada serão pagos exclusivamente pelo (opcional: Arrendante ou Arrendatário)

CLÁUSULA SÉTIMA - Caso o Arrendatário necessite de financiamentos para a exploração de sua atividade, ele deverá pleiteá-los por sua conta e responsabilidade exclusiva junto aos bancos públicos e privados, cabendo ao Arrendador tão-somente a assinatura da respectiva carta de anuência, para fins de garantia pignoratícia, na forma da Lei 4.8729/65.

CLÁUSULA OITAVA - Se, durante a vigência deste contrato, o Arrendatário vier a contratar trabalhadores nas suas lavouras, ele ficará responsável por todas as obrigações de natureza trabalhista, previdenciária e acidentária, além de outros encargos para com esses trabalhadores, os quais não terão nenhum vínculo com o Arrendante.

CLÁUSULA NONA - O Arrendatário não poderá subarrendar, ceder ou emprestar no todo ou em parte o imóvel objeto deste contrato, bem como seus acessórios, sem o prévio consentimento por escrito do Arrendante.

CLÁUSULA DÉCIMA - Em hipótese alguma, o imóvel arrendado poderá ser utilizado para culturas ilegais de plantas psicotrópicas

CLÁUSULA DÉCIMA PRIMEIRA - Para a implantação de qualquer benfeitoria que não seja necessária no imóvel arrendado, o Arrendatário será obrigado a obter autorização prévia e por escrito do Arrendante.

CLÁUSULA DÉCIMA SEGUNDA - O Arrendatário fica obrigado a respeitar integralmente a legislação ambiental na utilização do imóvel arrendado, especialmente com referência à conservação dos recursos naturais. Assim, ele não poderá promover o corte de árvores, o desmatamento das matas ciliares e das áreas de preservação permanente, nem fazer represamento dos riachos que nascem ou atravessam o imóvel. Não poderá também permitir que pessoas estranhas adentrem o imóvel para a prática de qualquer espécie de caça ou pesca ilegais, proibição esta extensiva a ele próprio, seus familiares e empregados.

CLÁUSULA DÉCIMA TERCEIRA - Na hipótese de vir a ser desrespeitado qualquer dispositivo das cláusulas $10^{\mathrm{a}} \mathrm{e}$ $12^{\mathrm{a}}$ e disso resultar em autuações, o Arrendatário será responsabilizado civil, e criminalmente pela sua ação ou omissão. Nesse caso, ele arcará com o pagamento das eventuais multas, além das perdas e danos a que der causa.

CLÁUSULA DÉCIMA QUARTA - Os casos porventura omissos neste contrato serão resolvidos amigavelmente pelas partes, sempre que isto for possível, com base na eqüidade e nos usos e costumes locais.

CLÁUSULA DÉCIMA QUINTA - Para dirimir quaisquer dúvidas ou pendências relativas a este contrato, caso surjam, as partes recorrerão sempre ao juízo arbitral, nos termos dos arts. $2^{\circ}$ e $3^{\circ}$ da Lei $n^{\circ} 9.307$, de 23 de setembro de 1996. Para tanto, indicam desde já como competente a Corte Arbitral (ou o Conselho) de..., que deverá indicar os árbitros de sua Câmara Agrária. As decisões tomadas pela arbitragem deverão ser acatadas pelas partes condicionalmente, que só recorrerão Poder Judiciário para a solução dos casos de grande complexidade jurídica. Neste caso, o foro competente será sempre o do local do imóvel, com renúncia expressa a qualquer outro, por mais privilegiado que seja e independentemente do domicílio delas.

Por estarem, assim, de pleno e comum acordo, depois de haverem combinado, contratado, dando tudo por bom, firme e valioso, assinam o presente contrato em três vias de igual teor e forma na presença das duas testemunhas abaixo, que a tudo assistiram e também o assinam, nesta data. 